\title{
Knowledge, Skills And Abilities For Early Childhood Preservice Student Teachers: A Focus Group Approach
}

\section{Ezron Mangwaya}

\author{
Midlands State University Gweru Zimbabwe
} Email:mangwayaezron@yahoo.co.uk

\author{
Doi:10.5901/mjss.2013.v4n14p719
}

\begin{abstract}
The purpose of this study was to establish the competences (knowledge, skills and abilities) required of effective early childhood education teachers as perceived by student teachers and to suggesthow competences can be acquired by student teachers before joining the teaching profession.Focus groups were conducted with student teachers who had done teaching practice and those who had not in two teachers'colleges in Masvingo province of Zimbabwe. Results indicated that specific competences were required across the domains of learning (cognitive, psychomotor and affective). Academic preparation in teachers'colleges, field experiences and exposure to role models were suggested as useful ways of acquiring teaching competences.
\end{abstract}

Key words Knowledge, skills. Abilities, early childhood education, student teachers, focus group

\section{Introduction}

To say that skills required of early childhood education teachers exceed those of other teachers in the primary school is an understatement. Much is known about classroom skills required of teachers to be considered effective in a general sense, but how much do we really know about the attributes required to be an effective early childhood education teacher? This study sought to explore the unique characteristics required of early childhood education teachers, and the ways of preparing preservicestudent teachers for their ultimate role as competent and effective early childhood education teachers. Early childhood education teachers rely on knowledge, skills and abilities that are acquired and strengthened through preservice education and experiential learning while on teaching practice.

According to Lindner and Dooley (2002) knowledge is a body of information, supported by professionally acceptable theory and research that individuals use to perform effectively and successfully in a given task. Skill is present, observable competence to perform a learned psychomotor act. Effective performance of skills requires application of related knowledge. Ability, on the other hand is a present competence to perform an observable behaviour or a behaviour that results in observable outcomes. Collectively, knowledge, skills and abilities are referred to as competences. Competences are behavioural dimensions that help to identify effective from ineffective performance (Maxine,2009).

In early childhood education some studies have been conducted to examine teacher competences in general. Fewer studies have focused on knowledge, skills and abilities that early childhood education teachers should acquire in order to become effective. According to Meier and Marais (2007) early childhood teachers should be nurturing towards children, skilful communicators, good role models, patient and encourage children to accomplish tasks independently, willing to undergo professional development, allow children to learn though play and should work cooperatively with other members of staff. Meier and Marais, however, do not classify these competences. Furthermore they do not explain how such competences should and can be acquired. Lack of suchvital information may inhibit preservice teacher preparation in terms of curriculum revision, courses offered and other essential activities.

One way to classify competences across settings has been provided by Bloom(1956). Bloom's taxonomy classifies competences into three domains, namely, the cognitive, affective and the psychomotor. The cognitive domain focuses on thinking and knowledge; the affective domain focuses on feelings and emotions and the psychomotor domain focuses on physical skills and tasks (Bloom, Harrow and Krathworl, 2006). Researchers note that it is the interplay among the domains that is important. Numerous studies have addressed specific characterisitics of effective classroom teachers in general. One of the most noted of these studies was conducted by Rosenshine and Furst (1971). They reviewed 51 previous studies on teacher effectiveness in an attempt to identify the most important characteristics impacting good 
teaching. Their efforts produced a list of items taught in most preservice teacher education courses, namely, clarity, variability, enthusiasm, student opportunity to learn material, and task orientation. Young (1990) also identifiedadditional characteristics such as ability to plan and execute lessons, monitor pupils learning, conduct lessons based on a variety of methods, and maintain rapport with learners.

The question we should ask ourselves as teacher educators is: How can we ensure that preservice students majoring in early childhood education leave teacher preparation programmes with a comprehensive set of knowledge, skills and abilities necessary to be effective. Most students are exposed to the gamut of competences particularly unique to early childhood education teachers through preservice classes. However, intuitively, we know that mere "exposure" simply does not result in effective learning and transfer of appropriate competences required. Teaching practice has been relied upon as a primary experiential means for preservice teachers to develop most of the skills required inside and outside the classroom (Fritz and Miller, 2003). Though most early childhood education teachers will not debate the importance of teaching practice, it is possible that this means of exposure is not totally effective in providing all of the experiences necessary for preservice teachers to fully develop into competent early childhood education teachers in all areas.

\section{Purpose of the study}

Firstly, this study attempts to determine the competences (knowledge, skills and abilities) required of effective early childhood education teachers inside and outside the classroom. Secondly, the study proposes ways through which preserviceearly childhood education student teachers can gain competences needed to be effective prior to entering the teaching profession.

\section{Research questions}

This study was guided by two research questions:

a) What are the knowledge, skills and abilities (competences) needed to be a successful early childhood education teacher as perceived by preservicestudent teachers?

b) How do preservicestudent teachers acquire such knowledge, skills and abilities?

\section{Methods}

The qualitative method of focus groups was deemed to be the most appropriate technique for addressing the above research questions. According to Chalofsky (1999) focus groups are carefully planned group meetings designed to collect perceptions and information on a defined area of intererest. Focus groups are different from interviews in that the facilitator encourages participants to interact and share ideas related to one another's comments (Litchman,2010). This study used focus groups withpreservice early childhood education student teachers from two teacher education colleges with regard to competences needed to be a successful early childhood education teacher and possible ways preservice early childhood education student teachers can acquire these competences before entering the profession. Current preservice early childhood education student teachers at a government teachers'college and at a private (mission) teachers'college in the Masvingo province of Zimbabwe were solicited for participation.

\section{Purposive samples}

The two lecturers-in-charge of early childhood education in each teachers'college served as gatekeepers to identify two purposive samples (one which consisted of student teachers who have done teaching practice and another sample of students preparing to go out on teaching practice). Sources differ on appropriate focus group sample size, but they generally range from 6 -15 participants (Larson, Grudens-Schulk and Allen, 2004; Kruger and Casey,2000; Berg,2001). Sixteen early childhood education student teachers who had done teaching practice were purposively selected from a government teachers' college and thirteen who had not done teaching practice werealso selected. From the private (mission) teachers'college fifteen early childhood education student teachers who had done teaching practice and twelve who had not done teaching practice were selected. Participation was voluntary and informed consent forms were completed by all participants. 


\section{Data gathering procedures}

Two focus group sessions were held at each teachers'college and each session lasted approximately one and half hours. All participants were coded with letters (TP - student who has been on teaching practice; NTP - student who has not been on teaching practice) and numbered in the order that they first spoke for confidentiality. Dialogue was encouraged and participants could speak as often as they felt they had something to contribute (Denzin and Lincoln, 2008). These focus group sessions were conducted during early childhood education student teachers' normal class time. During all sessions participants were assured that the information they shared would not be associated with them individually. Focus group sessions were audio recorded and notes were taken regarding student reactions to one another's comments.

\section{Data analysis}

The constant comparative method (Guba and Lincoln,1985) was used to analyse data from focus group interviews. Using this methodology, theory may be generated from data, or, if existing (grounded) theories are appropriate, then these can be compared and elaborated (theoretical elaboration). According to Strauss and Corbin (1998:275) "certain general procedures have made this methodology effective and influential. Besides the constant making of comparisons, systematic asking of generative and concept related questions, theoretical sampling, systematic coding and conceptual integration can also be utilised." The domains of knowledge (Bloom,1956) were used as the existing theoretical constructs for comparison and elaboration.

\section{Findings}

Competences identified by the four focus groups can be divided into three domains, namely, the cognitive (knowledge), psychomotor (skills) and the affective (attitudes,attributes or abilities) domains.As intimated earlier on, although the domains provide a useful way to separate the competences, it is the interplay of the domains, or how they are combined, that helps individuals to be successful in teaching early childhood education learners.

\subsection{Cognitive domain}

For the knowledge necessary for success in early childhood education teaching both student teachers who had gone on teaching practice and those who had not identified instructional theory (pedagogy), leadership theory, and broad knowledge of early childhood education along with early childhood content mastery in all subjects. Those students who had done teaching practice shared two unique knowledge areas that were based upon their school-based experiences. The first prominent theme involved being knowledgeable about the early childhood education programme in order to be able to communicate effectively to a variety of constituent groups(parents, other teachers, and school administrators). One student teacher declared, "I know more about early childhood education than other teachers and parents and I sometimes forget that I need to step back and explain things." The second area identified by students who had been on teaching practice focussed on classroom management policies and procedures, especially with respect to gaining and keeping early childhood education students' attention considering that early childhood education learners have a limited span of attention.

\subsection{Psychomotor domain}

Early childhood student teachers who had had teaching practice experience and those who had not expressed several skills that are required to be an effective early childhood education teacher. Both groups recognized that planning and organisational skills were paramount. Additionally, participants believed that theoretical areas should be translated into practice. For instance lesson presentation skillsand using a variety of teaching methods were shared as being important. Specifically, the ability to use different teaching media well was seen as an important skill. Furthermore, time management, enabling pupils to learn through play and being skilful communicators were considered as important practical skills early childhood teachers should develop. Student teachers who had done teaching practice shared unique perspectives on skills necessary for the profession. This group identified ability to work with diverse learners, decision making and facilitation skills as prerequisite skills for every early childhood education teacher. Additionally, they 
mentioned programme improvement, people skills, multitasking and classroom management skills. One such student teacher noted that early childhood education teachers must be able to adjustearly childhood content to suit the different learner abilities.

\subsection{Affective domain}

The most interesting finding from this study focuses on the vast array of affective domain attributes identified as necessary for early childhood education teaching. The 'intangibles' that were perceived as necessary by both focus groups in the two teachers' colleges included patience, being a life long learner, caring, appreciating and recognizing differences among early childhood education learners. Commitment to work, seen as a willingness to work hard and long hours was also rated highly by all the focus groups. Participants universally indicated that "the ability to tailor to each early childhood education learner" was a necessary skill and that teachers needed to be continuous learners to stay current on early childhood education practices and technologies. Students who had done teaching practice noted that early childhood education teachers should demonstrate high levels of dedication through exhibiting heightened responsibility, creativity, enthusiasm and a high sense of internal motivation. Additionally, they observed that early childhood education teachers should exhibit flexibility and open-mindedness. This group of participants indicated that teachers must expect the unexpected and "realize that not all early childhood learners have the same passion." Participants opined that these attributes allow early childhood education teachers to love their work and avoid burn-out due to long hours and responsibilities required of them by school authorities and the school community.

\section{Acquisition of Competences}

From the data academic preparation, field experiences and exposure to role models emerged as the major avenues through which individuals acquired the knowledge, skills and abilities required of early childhood education teachers. As shared previously, in the section on findings, several participants indicated that quality early childhood education teachers possess both broad knowledge of early childhood education and specific subject area expertise. According to participants this knowledge is best gained through academic preparation at teachers' college. For instance theoretical principles of child development, theories of learning, motivation theories, methods of teaching, specific subject content and theories of play, among other topics, should be acquired through theory lectures at college.

Participants universally expressed that all necessary knowledge could not be gained or acquired throughacademic preparation. As one student teacher observed "general knowledge is learned in college, but nothing really prepares you for being an early childhood education teacher...some skills cannot be taught in the lecture room." All focus groups identified the importance of field experiences such as teaching practice and interaction with other teachers in the field. According to the student teachers, teaching practice provides opportunities to try out what has been learnt at college. In particular, teaching real learners and observing as well as solving their challenges is key to acquiring the necessary teaching skills and abilities that make one an effective early childhood education teacher.

Exposure to role models was also identified as an important component of learning how to be an effective early childhood education teacher.There was consensus among participants that they learnt how to be effective early childhood education teachers by observing their own lecturers (during demonstration lessons) and mentors when on teaching practice. Participants also indicated that early childhood education teachers should enjoy what they are doing and exude enthusiasm. Additionally, participants observed that attributes such as patience, caring, and commitment are learnt from observation and exposure to role models.

\section{Conclusions, Implications and Recommendations}

The purpose of this study was to determine competences (knowledge, skills and abilities) required of effective early childhood education teachers as perceived by student teachers. Secondly, the study was meant to establish ways in whihpreservice student teachers can gain the competences needed to be effective prior to entering the teaching profession. Based on the findings of this study, several conclusions were drawn. With regard the first research question both student teachers who had done teaching practice and those who had not identified competences across the three domains of learning (knowledge, skills and abilities) as being important. This supports the findings of Roberts and Dyer (2004) on teaching skills necessary to become an effective early childhood education teacher.

While those student teachers who had done teaching practice and those who had not agreed upon a number of 
knowledge and skills, surprisingly, those relating to the affective domain resulted in the most consensus among the four focus groups. Those students who had done teaching practice identified broader, and more well rounded skills and abilities than those who had not done teaching practice. The later tended to focus on more specific, skills- based abilities. With regard to the second research question, participants suggested several mechanisms for effectively preparing early childhood education student teachers. These included field based experiences, theory courses at college and exposure to role models. This finding concurs with research conducted by Fritz and Miller (2003) where student teaching was identified as an important component of teacher preparation. It also supports Findlay's (1992) findings whereby teachers found higher levels of competence through formal education and on-the-job experience.

This study provides a student teacher's views on the competences required of an effective early childhood education teacher as well as the mechanisms that can be utilized to acquire these competences. Further studies involving teacher educators and teacher mentors are recommended so that teacher education programmes can be better improved so as to produce effective early childhood education teachers. Additionally, because of the type of methodology used, it is also recommended that the study be replicated in other teachers' colleges in Zimbabwe in order to establish whether the results are similar in other institutions.

\section{References}

Berg, B. (2001) Qualitative research methods for social sciences. Needham Heights: Allyn and Bacon.

Bloom, B. (1956) Taxonomy of educational objectives: Handbook 1 the cognitive domain. New York: David Mckay.

Chalofsky, N. (1999) How to conduct focus groups. Alexandria: American Society for Training and Development.

Denzin, N. and Lincoln, Y. (2008) The landscape of qualitative research: theories and issues. Thousand Oaks: Sage Publications.

Findlay,H. (1992) Acquiring professional teaching competences. London: Allyn and Bacon.

Fritz, C.A. and Miller, G. (2003) Concerns expressed by student teachers on teachingpractice. Thousand Oaks: Sage Publications.

Guba,E.G. and Lincoln,Y.S. (1985) Naturalistic inquiry. Beverly Hills: Sage Publications.

Krueger, R. and Casey, M. (2000) Focus groups: A practical guide for applied research. Thousand Oaks: Sage Publications.

Larson, K., Grudens-Schulk, N. and Allen,B. (2004) Can you call it a focus group? Ames: lowa State University.

Lindner, J. and Dooley, K. (2002) Discrepancies in comptences between students on campus and those on teaching practice. American Journal of Education 15(2) $25-40$.

Litchman,M. (2010) Qualitative research in education: a user's guide. Thousand Oaks: Sage Publications.

Meier, C. and Marais, P. (2007) Educational management in early childhood development. Pretoria: Van Schaik Publishers.

Roberts, T. and Dyer, J. (2004) Characteristics of effective teachers.Journal of Education 47(1) 77 - 90.

Rosenshine,B. and Furst, N. (1971) Research on teacher performance criteria. Englewood Cliffs: Prentice Hall.

Strauss, A.and Corbin, J. (1998) Grounded theory methodology. In N.K. Denzin and Lincoln (eds) Handbook of qualitative research Thousand Oaks: Sage Publications.

Young, M. (1990) Characteristics of high potential and at risk teachers. Action In Teacher Education 11(4) 35 - 39. 
